\title{
Aneurisma de la vena cava superior
}

\section{Aneurisma de la vena eavasuperior}

\author{
Luisa F. Enciso, Daniel Santa • Ciudadxxx
}

Paciente de 47 años quien consulta por cuadro de disnea progresiva hasta hacerse en reposo.

Síntomas progresivos inicialmente como disnea de levea a moderados esfuerzos 10 días previos a consulta que empeoraron con el reposo y que interrumpían las actividades diarias asociada a edemas de miembros inferiores y bipalpebral. Igualmente refería ortopnea y disnea paroxística nocturna sin tos o cianosis.

Un mes previo a su consulta inicial, la paciente inicia con placas eritematosas en ambas piernas acompañadas tanto de artralgias como astenia y eritema malar. Posteriormente se le confirmó el diagnóstico de lupus eritematoso sistémico.

Se le toma como imagen de valoración inicial, radiografía de tórax con imagen de masa a nivel de mediastino anterior por lo que se lleva a escanografía de tórax con contraste revelando imagen mostrada compatible con dilatación aneurismática de vena cava superior por lo que fue tratada inicialmente para cuadro de falla cardiaca. Posteriormente se le practica cavografía reportada como aneurisma sacular de vena cava superior sin trombos en su interior. La paciente fue llevada exitosamente a corrección quirúrgica.

La mayoría de lesiones vistas en mediastino gracias a las imágenes son secundarias a masas o tumores. Sin embargo, existe un porcentaje pequeño de lesiones vasculares: $10 \%$ del total de las lesiones del mediastino y de este $10 \%$ la mayoría son lesiones arteriales. Los aneurismas de la vena cada superior es extremadamente raros dividiéndose en saculares y fusiformes; reportando la mayor serie de casos 27 pacientes de aneurismas de predominio fusiforme y los aneurismas saculares son aún menos frecuentes, encontrando en la literatura únicamente 10 casos reportados (1). La primera descripción de este tipo de lesiones data del año 1950 por Abbot y es éste mismo autor quien los divide en fusiformes y saculares (2).

Usualmente, estos aneurismas son asintomáticos y se encuentran incidentalmente en radiografías de tórax y la mayoría de veces el diagnóstico definitivo se hace de manera intraoperatoria sin embargo dada la baja incidencia no existe un algoritmo claro de tratamiento. Ciertos autores prefieren observación sobre todo en los pacientes asintomáticos, sin embargo otros autores consideran que la corrección quirúrgica es de importancia sobre todo en los paciente con aneurismas saculares ante el riesgo de embolismo pulmonar, parálisis frénica o ruptura. $(1,2)$ No se ha descrito aún tratamiento endovascular para este tipo de aneurismas (3).

\section{Referencias}

K.Gozdziuk, E.Czekajska-Chehab, A.Wrona,A.Tomaszewski, A. Drop. Saccular Aneurysm of the SuperiorVena Cava Detected by ComputedTomography and SuccessfullyTreated With Surgery. Ann Thorac Surg 2004; 78: e94 -5.

I. Osorio, M. Lomas, M. Hidalgo, J. Perea. Aneurisma sacular de la vena cava superior. J Clin Oncol 2010.

T.R. Enright, J.P. Kanne Saccular superior vena cava aneurysm d incidentaldiagnosis by MDCT. Clin Radiol 2010; 65(5): 421-2.

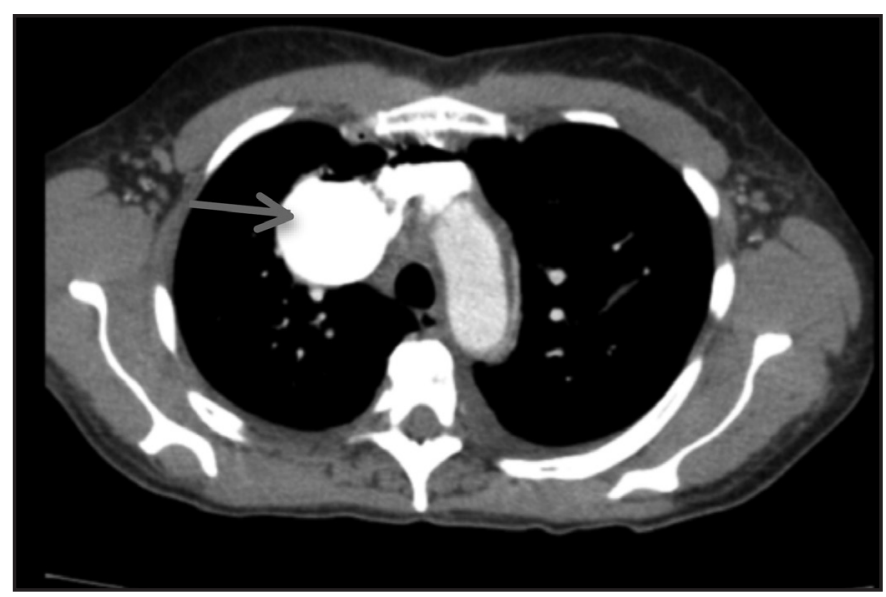

Figura 1. TAC de tórax con contraste.

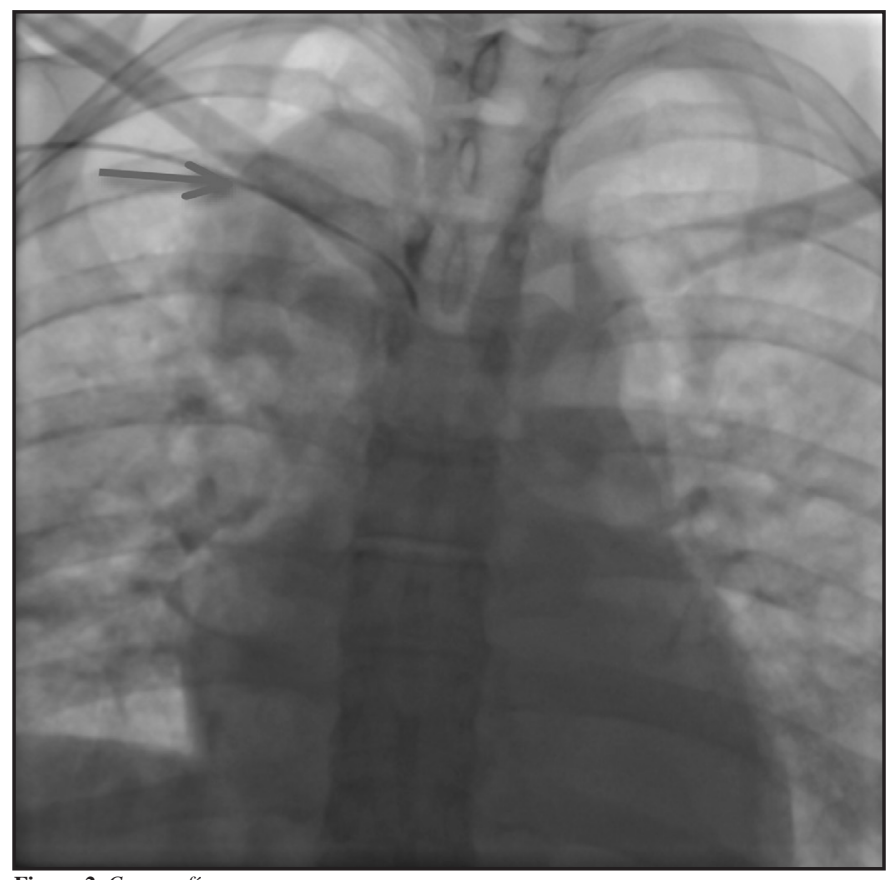

Figura 2. Cavografía.

Dra. Luisa F. Enciso B.: R2 Medicina Interna HMC - UMNG; Dr. Daniel Santa Botero: Especialista Medicina Interna HMC

Correspondencia. Dra. Luisa F. Enciso B.

E-mail: $\operatorname{zxxxxxxxxxx}$

Recibido: 31/VII/2013 Aceptado: 17/XII/2013 